\title{
Papers
}

\section{Hepatic histology of patients with HIV infection and chronic hepatitis $C$ treated with interferon}

\author{
Renzo Boldorini, Paolo Viganò, Guido Monga, Manuela Nebuloni, Antonietta Cargnel, \\ Guido Gubertini, Giuseppe Migliaretti, Giulio Costanzi
}

Dipartimento di

Scienze Mediche,

Facoltà di Medicina e

Chirurgia di Torino,

sede di Novara

R Boldorini

G Monga

G Migliaretti

Unità Operativa di

Malattie Infettive,

Ospedale di Legnano

$P$ Viganò

Il Divisione di Malattie Infettive, Ospedale L.

Sacco, Milano

A Cargnel

G Gubertini

V Cattedra di

Anatomia Patologica, Istituto di Scienze

Biomediche

M Nebuloni

G Costanzi

Correspondence to: Dr Boldorini, Servizio di Anatomia Patologica,

Ospedale Maggiore della

Carità, Corso Mazzini 18,

28100 Novara, Italy.

Accepted for publication 12 June 1997

\begin{abstract}
Aims-To evaluate the histological changes seen in liver biopsies after interferon (IFN) treatment in patients with chronic hepatitis $C$ and human immunodeficiency virus (HIV) infection.

Methods-Twenty four intravenous drug users with chronic hepatitis $\mathbf{C}$ were investigated histologically before beginning a 12 month course of IFN treatment and 18 months later. Twelve were HIV positive, without opportunistic or other viral infections (group A), and 12 were HIV negative (group B).

Results-According to alanine aminotransferase concentrations, four sustained responders and eight non-responders were found in group $A$; six sustained responders, five relapsers, and one nonresponder were found in group B. HCV RNA became negative in one sustained responder of group $A$ and in the six sustained responders of group $B$. When histological findings of biopsies performed before therapy and 18 months later were compared, no significant changes in the mean value of Knodell's index and subindices were found in group $A$, whereas in group B Knodell's index, piecemeal necrosis, and focal hepatocellular necrosis decreased significantly.

Conclusions-In chronic hepatitis C, coinfection with HIV showed a tendency towards a lower response to IFN, although this did not reach statistical significance; however, none of the HIV positive patients developed cirrhosis during the follow up and this should be considered in clinical management of such patients. (f Clin Pathol 1997;50:735-740)
\end{abstract}

Keywords: chronic hepatitis C; human immunodeficiency virus; liver biopsy

Hepatitis $\mathrm{C}$ virus (HCV) infection is frequent in patients with acquired immunodeficiency syndrome (AIDS), ${ }^{1}$ especially in intravenous drug users or subjects who have received blood transfusions. ${ }^{2}$ Its clinical outcome is reported to be worse than in patients without human immunodeficiency virus (HIV) infection. Berk et $a l^{3}$ described a case of chronic hepatitis $\mathrm{C}$ infection in an HIV positive patient with severe liver cell damage resembling that of autoimmune type, and Martin et $a l^{4}$ found a rapid progression to liver cirrhosis in three HIV positive patients co-infected with $\mathrm{HCV}$.

The unfavourable evolution of chronic hepatitis C in HIV positive subjects could be caused solely by the severe impairment of the immunological system, or by the simultaneous presence of opportunistic agents or neoplasms, which are common in HIV positive patients.

Several studies have shown that interferon (IFN) therapy is of potential benefit to patients with chronic hepatitis $\mathrm{C}$, and both clinical and morphological effects in treated patients have been reported..$^{6-9}$ On the contrary, only a few studies have evaluated its effects in chronic hepatitis C in HIV positive patients, and they have been mainly from the clinical point of view. ${ }^{10-12}$ To our knowledge, no study has thoroughly examined the histological changes in liver biopsies induced by IFN in HIV positive patients.

The aim of this study was to describe the effects on liver histology of a 12 month course of IFN in a group of HIV positive patients, and to compare the results with those from a group of HIV negative patients selected for similar age, sex, risk factors, and duration of intravenous drug addiction, all with chronic hepatitis C.

\section{Materials and methods}

PATIENT SELECTION

Twenty four patients, all intravenous drug users with chronic hepatitis $\mathrm{C}$, were selected for the study and divided into two groups: 12 HIV positive patients (group A), and $12 \mathrm{HIV}$ negative patients (group B). The mean age for both groups was 27 years (range 21-37 for group A and 23-35 for group B); both comprised seven men and five women; the duration of intravenous drug addiction was similar in the two groups (mean seven years for group A and six years for group B).

The patients had been referred to the 2 nd Division of the Infectious Disease Unit of L. Sacco Hospital, Milan, from 1991 to 1994 , and 
Table 1 Changes in serum ALT with IFN treatment and HCV genotypes in $12 \mathrm{HIV}$ positive patients

\begin{tabular}{|c|c|c|c|c|c|}
\hline \multirow[b]{2}{*}{ Case } & \multicolumn{3}{|c|}{$A L T$ concentration (IU/l) } & \multirow[b]{2}{*}{ HCV genotype } & \multirow{2}{*}{$\begin{array}{l}\text { Response to } \\
\text { IFN }\end{array}$} \\
\hline & Time 0 & Time 12 & Time 18 & & \\
\hline 1 & 63 & 119 & 97 & $3 a$ & NR \\
\hline 2 & 91 & 94 & 300 & $3 a$ & NR \\
\hline 3 & 81 & 46 & 108 & $1 \mathrm{~b}$ & NR \\
\hline 4 & 208 & 28 & 37 & $1 \mathrm{~b}$ & SR \\
\hline 5 & 104 & 80 & 57 & $3 a$ & NR \\
\hline 6 & 131 & 21 & 26 & $2 a$ & SR \\
\hline 7 & 182 & 57 & 32 & $1 \mathrm{a}$ & SR \\
\hline 8 & 71 & 38 & 36 & $3 a$ & SR \\
\hline 9 & 154 & 153 & 196 & $1 b$ & NR \\
\hline 10 & 94 & 79 & 84 & $3 a$ & NR \\
\hline 11 & 75 & 54 & 69 & $3 a$ & NR \\
\hline 12 & 116 & 146 & 228 & 1a & NR \\
\hline
\end{tabular}

Time 0 , before treatment; time 12 , at the end of 12 months' treatment; time 18 , after a further six months of follow up. HCV genotype according to Simmond's classification. ${ }^{17}$

$\mathrm{NR}$, non-responder; SR, sustained responder.

Table 2 Changes in serum ALT with IFN treatment and HCV genotypes in 12 HIV negative patients

\begin{tabular}{llllll}
\hline \multirow{5}{*}{ Case } & \multicolumn{2}{l}{ ALT concentration (IU/l) } & & \\
\cline { 2 - 4 } & Time 0 & Time 12 & Time 18 & HCV genotype & $\begin{array}{l}\text { Response to } \\
\text { IFN }\end{array}$ \\
\hline 1 & 147 & 21 & 17 & $3 \mathrm{a}$ & SR \\
2 & 274 & 16 & 109 & $2 \mathrm{a}$ & Relapser \\
3 & 244 & 12 & 10 & $1 \mathrm{~b}$ & SR \\
4 & 197 & 14 & 121 & $2 \mathrm{a}$ & Relapser \\
5 & 68 & 17 & 17 & $3 \mathrm{a}$ & SR \\
6 & 123 & 28 & 97 & $2 \mathrm{a}$ & Relapser \\
7 & 108 & 23 & 152 & $1 \mathrm{a}$ & Relapser \\
8 & 205 & 36 & 19 & $3 \mathrm{a}$ & SR \\
9 & 105 & 16 & 17 & $3 \mathrm{a}$ & SR \\
10 & 75 & 62 & 120 & $1 \mathrm{~b}$ & NR \\
11 & 82 & 16 & 87 & $3 \mathrm{a}$ & Relapser \\
12 & 87 & 24 & 29 & $3 \mathrm{a}$ & SR \\
\hline
\end{tabular}

Time 0 , before treatment; time 12 , at the end of 12 months' treatment; time 18 , after a further six months of follow up. HCV genotype according to Simmond's classification. ${ }^{17}$ $\mathrm{NR}$, non-responder; SR, sustained responder.

fulfilled the following criteria: (1) elevation of serum alanine aminotransferase (ALT) levels for longer than six months (more than twice the upper limit of normal values, 10-40 IU/1);

(2) no evidence of hepatitis $B$ virus infection (absence of detectable hepatitis B surface antigens and HBV DNA in serum) or other causes of chronic viral hepatitis by appropriate laboratory tests, and (for patients of group A) absence of opportunistic infections; (3) CD4 cell count more than 200 cells $/ \mathrm{mm}^{3}$; (4) no zidovudine or other antiviral therapy before or during the study period.

In HIV positive patients, mean CD4 count was 465 cells $/ \mathrm{mm}^{3}$ (range 231-819) before the treatment, and 414 cells $/ \mathrm{mm}^{3}$ (range 234-950) 18 months later.

SEROLOGY

Anti-HCV antibodies were detected by the second generation enzyme linked immunosorbent assay (ELISA) (Ortho Diagnostic Systems, Raritan, New Jersey, USA); HCV RNA was detected in serum with a nested polymerase chain reaction (nPCR) and the amplification products were detected by DNA enzyme immunoassay (Sorin Biomedica, Saluggia, Italy). HCV genotyping was carried out using a type specific detection system of the PCR amplified 5 ' non-coding region of the HCV genome on the serum collected at the beginning of treatment. ${ }^{13}$
Group A had anti-HIV antibodies detected by ELISA (Pasteur, Paris, France) and confirmed by western blot assay (Pasteur). The p24 antigen of HIV was detected by an immunoenzyme assay (Abbott Laboratories, North Chicago, Illinois, USA).

Written informed consent was obtained from all patients and the trial was approved by the local ethics committee.

\section{TREATMENT SCHEDULE}

Lymphoblastoid $\alpha$ 2n IFN (Wellcome Research Laboratories, Kent, UK) was injected subcutaneously according to the following schedule: 6 million units three times a week for six months (induction phase), 3 million units three times a week for a further six months (maintenance phase).

Serum ALT concentrations were assessed before treatment (time 0 ), at the end of treatment (time 12), and six months later (time 18). According to the outcome of serum ALT, the patients were defined as: sustained responders (normal serum ALT achieved at time 12 and lasting throughout follow up) and nonresponders (no significative changes in ALT during the therapy). Post-treatment relapsers were defined as the cases in which ALT levels were normalised at the end of therapy but increased above the normal range six months after discontinuation of therapy.

\section{EVALUATION OF LIVER HISTOLOGY}

Liver needle biopsies were obtained with a modified Menghini technique, at times 0 and 18. The samples were fixed in formalin and embedded in paraffin; $5 \mathrm{~mm}$ thick sections were stained with haematoxylin and eosin, Masson's trichrome, periodic acid-Schiff after diastase digestion, Gomori's method for reticulin, and Perls method for evaluation of iron stores.

The morphological changes were evaluated by the histological activity index, according to Knodell et $a l^{14}$ and by the recently proposed Desmet's classification of chronic hepatitis. ${ }^{15}$

Histological assessment of hepatic iron stores was performed using a score system proposed by Searle et al. ${ }^{16}$

\section{STATISTICAL ANALYSIS}

Data from Knodell's index and subindices were analysed by the Wilcoxon matched pairs non-parametric test. The changes in serum ALT levels were analysed by the parametric $t$ test for independent samples to evaluate their changes from time 0 to times 12 and 18 between the two groups. Serological and biochemical responses between the two groups were compared by Fisher's exact test. Significance was established at $\mathrm{p}<0.05$.

\section{Results}

Serum ALT values are summarised in tables 1 and 2 . Thei mean values at the beginning of therapy were higher in group B than in group A (142 and 114, respectively; not significant), decreased more considerably at the end of the therapy in group B than in group A (24 and 76, 
Table 3 Histological changes induced by IFN treatment in 12 HIV positive patients

\begin{tabular}{|c|c|c|c|c|c|c|c|}
\hline Case & Time & $\begin{array}{l}\text { Piecemeal } \\
\text { necrosis }\end{array}$ & $\begin{array}{l}\text { Focal } \\
\text { hepatocellular } \\
\text { necrosis }\end{array}$ & $\begin{array}{l}\text { Portal } \\
\text { inflammation }\end{array}$ & Fibrosis & $\begin{array}{l}\text { Score } \\
(H A I)\end{array}$ & $\begin{array}{l}\text { Histological } \\
\text { diagnosis of } \mathrm{CH}\end{array}$ \\
\hline \multirow[t]{2}{*}{1} & 0 & 1 & 1 & 3 & 1 & 6 & Mild \\
\hline & 18 & 3 & 1 & 3 & 1 & 8 & Mild \\
\hline \multirow[t]{2}{*}{2} & 0 & 1 & 1 & 1 & 3 & 6 & Mild \\
\hline & 18 & 3 & 3 & 3 & 3 & 12 & Moderate \\
\hline \multirow[t]{2}{*}{3} & 0 & 3 & 3 & 3 & 1 & 10 & Moderate \\
\hline & 18 & 1 & 3 & 3 & 3 & 10 & Moderate \\
\hline \multirow[t]{2}{*}{4} & 0 & 3 & 3 & 3 & 1 & 10 & Moderate \\
\hline & 18 & 1 & 1 & 3 & 1 & 6 & Mild \\
\hline \multirow[t]{2}{*}{5} & 0 & 3 & 3 & 3 & 3 & 12 & Moderate \\
\hline & 18 & 5 & 3 & 4 & 3 & 15 & Severe \\
\hline \multirow[t]{2}{*}{6} & 0 & 5 & 3 & 3 & 3 & 14 & Severe \\
\hline & 18 & 3 & 1 & 3 & 3 & 10 & Moderate \\
\hline \multirow[t]{2}{*}{7} & 0 & 1 & 3 & 1 & 1 & 6 & Mild \\
\hline & 18 & 3 & 3 & 3 & 1 & 10 & Moderate \\
\hline \multirow[t]{2}{*}{8} & 0 & 3 & 1 & 3 & 1 & 10 & Moderate \\
\hline & 18 & 1 & 1 & 3 & 3 & 8 & Mild \\
\hline \multirow[t]{2}{*}{9} & 0 & 1 & 3 & 1 & 1 & 6 & Mild \\
\hline & 18 & 3 & 3 & 3 & 1 & 10 & Moderate \\
\hline \multirow[t]{2}{*}{10} & 0 & 3 & 3 & 3 & 1 & 10 & Moderate \\
\hline & 18 & 3 & 3 & 3 & 3 & 12 & Moderate \\
\hline \multirow[t]{2}{*}{11} & 0 & 5 & 4 & 4 & 3 & 16 & Severe \\
\hline & 18 & 4 & 1 & 3 & 3 & 11 & Moderate \\
\hline \multirow[t]{2}{*}{12} & 0 & 1 & 3 & 3 & 3 & 10 & Moderate \\
\hline & 18 & 1 & 3 & 3 & 3 & 10 & Moderate \\
\hline
\end{tabular}

Time 0 , before treatment; time 18 , six months after treatment stopped.

HAI, histological activity index according to Knodell's criteria ${ }^{14} ; \mathrm{CH}$, chronic hepatitis classified according to Desmet et al..$^{15}$

Table 4 Histological changes induced by IFN treatment in 12 HIV negative patients

\begin{tabular}{|c|c|c|c|c|c|c|c|}
\hline Case & Time & $\begin{array}{l}\text { Piecemeal } \\
\text { necrosis }\end{array}$ & $\begin{array}{l}\text { Focal } \\
\text { hepatocellular } \\
\text { necrosis }\end{array}$ & $\begin{array}{l}\text { Portal } \\
\text { inflammation }\end{array}$ & Fibrosis & $\begin{array}{l}\text { Score } \\
(H A I)\end{array}$ & $\begin{array}{l}\text { Histological } \\
\text { diagnosis of } \mathrm{CH}\end{array}$ \\
\hline \multirow[t]{2}{*}{1} & 0 & 1 & 3 & 3 & 1 & 8 & Mild \\
\hline & 18 & 0 & 0 & 0 & 1 & 1 & Minimal \\
\hline \multirow[t]{2}{*}{2} & 0 & 1 & 3 & 1 & 3 & 8 & Mild \\
\hline & 18 & 1 & 0 & 1 & 1 & 3 & Minimal \\
\hline \multirow[t]{2}{*}{3} & 0 & 1 & 1 & 1 & 1 & 4 & Mild \\
\hline & 18 & 0 & 0 & 1 & 1 & 2 & Minimal \\
\hline \multirow[t]{2}{*}{4} & 0 & 1 & 3 & 3 & 1 & 8 & Mild \\
\hline & 18 & 1 & 1 & 3 & 1 & 6 & Mild \\
\hline \multirow[t]{2}{*}{5} & 0 & 3 & 1 & 3 & 1 & 8 & Mild \\
\hline & 18 & 0 & 0 & 1 & 1 & 2 & Minimal \\
\hline \multirow[t]{2}{*}{6} & 0 & 1 & 1 & 1 & 1 & 4 & Mild \\
\hline & 18 & 0 & 1 & 0 & 1 & 2 & Minimal \\
\hline \multirow[t]{2}{*}{7} & 0 & 1 & 0 & 1 & 1 & 3 & Minimal \\
\hline & 18 & 0 & 1 & 1 & 1 & 3 & Minimal \\
\hline \multirow[t]{2}{*}{8} & 0 & 3 & 3 & 1 & 1 & 8 & Mild \\
\hline & 18 & 1 & 1 & 1 & 1 & 4 & Mild \\
\hline \multirow[t]{2}{*}{9} & 0 & 1 & 1 & 1 & 1 & 4 & Mild \\
\hline & 18 & 0 & 0 & 1 & 1 & 2 & Minimal \\
\hline \multirow[t]{2}{*}{10} & 0 & 1 & 1 & 1 & 1 & 4 & Mild \\
\hline & 18 & 0 & 0 & 3 & 1 & 4 & Mild \\
\hline \multirow[t]{2}{*}{11} & 0 & 1 & 3 & 1 & 3 & 8 & Mild \\
\hline & 18 & 0 & 0 & 1 & 1 & 2 & Minimal \\
\hline \multirow[t]{2}{*}{12} & 0 & 1 & 1 & 1 & 1 & 4 & Mild \\
\hline & 18 & 0 & 0 & 1 & 1 & 2 & Minimal \\
\hline
\end{tabular}

Time 0 , before treatment; time 18 , six months after treatment stopped.

HAI, histological activity index according to Knodell's criteria ${ }^{14} ; \mathrm{CH}$, chronic hepatitis classified according to Desmet et al. ${ }^{15}$
$\mathrm{HCV}$ genotypes are compared with the response to IFN in tables 1 and 2; the changes in the histological picture induced by IFN at time 0 and 18 are reported in tables 3 and 4 .

IFN therapy had different histological effects in the two groups of patients. The mean value of the Knodell's index increased from 9.6 to 10.2 (not significant) in the HIV positive group, and decreased from 5.9 to 2.7 $(p<0.005)$ in the HIV negative group.

The response to IFN is better defined by evaluating the single parameters of Knodell's index. In group $A$, the mean values of piecemeal necrosis and focal hepatocellular necrosis did not change significantly (fig 1 ). In group $B$, these subindices decreased significantly (piecemeal necrosis, $\mathrm{p}<0.005$; focal hepatocellular necrosis, $p<0.008$ ) (fig 2). In both groups, the mean value of fibrosis and portal inflammation did not change significantly.

Using the classification of Desmet et $a l,{ }^{15}$ a worsening of the the histological picture was found in four patients in group A (cases $2,5,7$, and 9) (fig 1), while four patients $(4,6,8$, and 11) improved, and four patients $(1,3,10$, and 12) did not change their histological grading after therapy. On the contrary, no patient from group B worsened, eight improved $(1,2,3,5,6$, 9,11 , and 12) (fig 2), and in four patients the liver damage did not change significantly $(4,7$, 8 , and 10).

The evaluation of liver iron deposition showed fine granules, barely discernible at a magnification of $\times 250$ and $\times 400$ (grades 0 and 1 ); these were found mostly in the cytoplasm of hepatocytes and sinusoidal cells, and occasionally in the portal spaces, in all the cases.

\section{Discussion}

A large number of studies have found positive effects of IFN treatment in HIV negative patients with chronic hepatitis $\mathrm{C}$, with improvement of biochemical ${ }^{6101819}$ and histological pictures. ${ }^{8920}$ In detail, this therapy normalises ALT in about $25-45 \%$ of the patients, ${ }^{18} 19$ and variably decreases lobular, portal, or periportal damage, ${ }^{8}$ and even fibrosis. ${ }^{9}$ There are only a few papers in the literature reporting the effects of IFN on chronic hepatitis C in HIV positive patients, most of them being evaluated on the basis of biochemical responses only. ${ }^{10}{ }^{11}$ In addition, when histological studies were performed, only some of the cases seem to have been investigated and no scoring systems were used. ${ }^{12}$ Indeed, Boyer et $a l^{10}$ described the evolution of serum ALT after a six month course of IFN in $12 \mathrm{HIV}$ positive patients and did not find any differences in rates of response from those usually described in the literature for HIV negative patients. Liver biopsies were performed at the end of the therapy in only two cases and showed improvement in one patient and no response in the other. Dalton et al reported in an abstract, ${ }^{11}$ a normalisation of serum ALT in one of five HIV positive subjects with chronic hepatitis C after six months of therapy, but they did not report any data about the histological evolution. Marriott et $a l^{12}$ described the effects of high dose IFN in 14 classified as a sustained responder. At the end of the treatment, HCV RNA was negative in one patient from group A (case 4, a sustained responder), and in six sustained responders of group B (cases $1,3,5,8,9$, and 12) $(\mathrm{p}<0.05)$. 


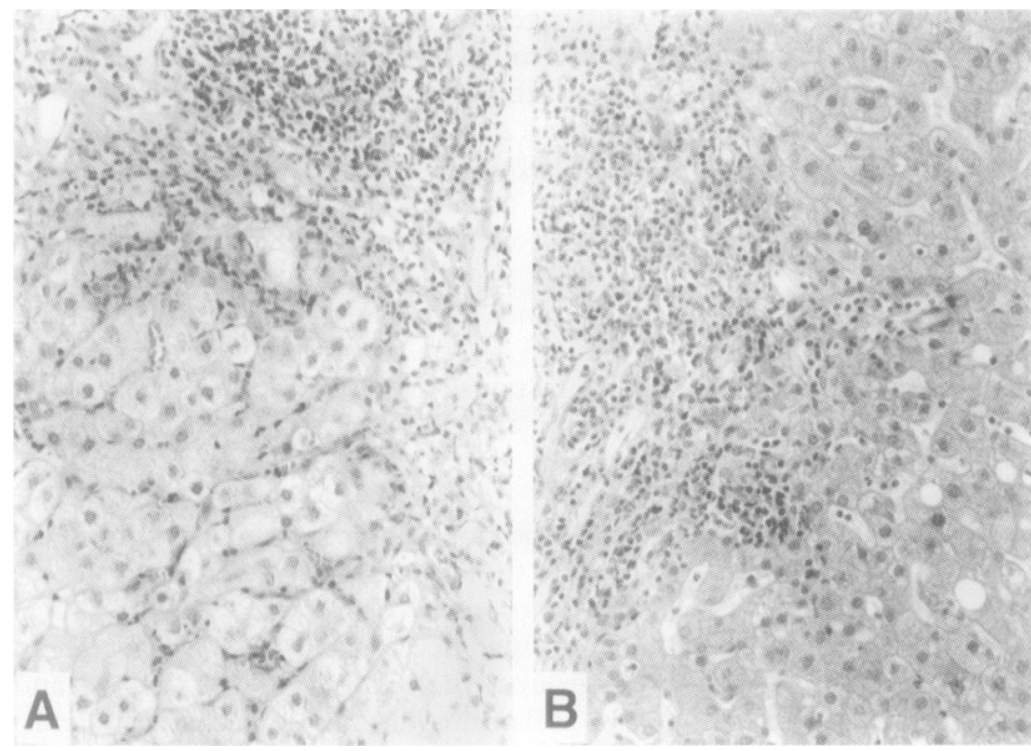

Figure 1 Liver biopsy of moderate chronic hepatitis $C$ in a patient with HIV infection (case number 10) (A) before and (B) six months after the end of interferon treatment. Note the persistence of piecemeal necrosis and portal inflammatory infiltrate. Haematoxylin and eosin, original magnification $\times 200$.

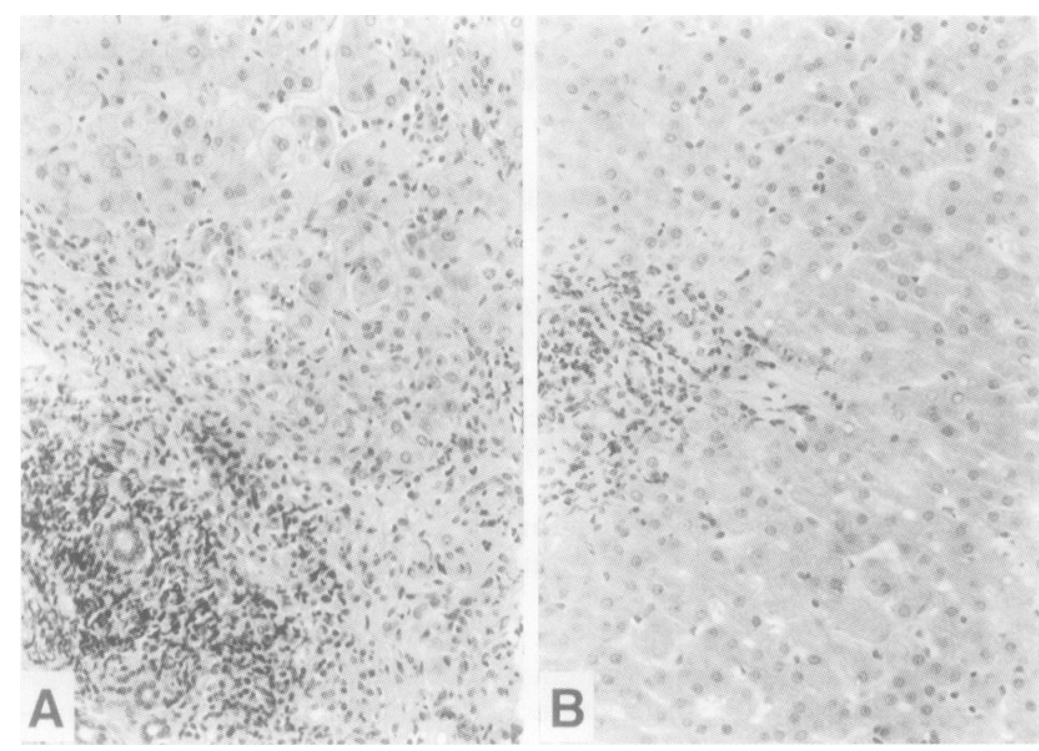

Figure 2 Liver biopsy of mild chronic hepatitis $C$ in an HIV negative patient (case number 2) (A) before and $(B)$ six months after the end of interferon treatment. Note that piecemeal necrosis and portal inflammatory infiltrate are considerably decreased in $(B)$.

Haematoxylin and eosin, original magnification $\times 200$.

HIV positive patients with chronic hepatitis C Liver biopsies were obtained from all the patients before the treatment but only six had a second biopsy six months after the end of therapy and in all of them the authors found an improvement of histology. However, they did not evaluate the changes in liver histology with scoring systems; and in addition, no data were available about the evolution of fibrosis or the grade of inflammation during treatment.

In the present study we considered the changes in liver damage after a 12 month therapy with IFN, in $12 \mathrm{HIV}$ positive, intravenous drug users with chronic hepatitis C. This group was compared with a group of 12 patients with chronic hepatitis $\mathrm{C}$, showing the same risk factors, mean age, male:female ratio, and duration of intravenous drug addiction, but differing in the absence of HIV infection.
The number of cases was relatively small, as it is difficult to find patients fulfilling the above reported criteria in HIV positive subjects (especially the absence of other viral and or opportunistic infections). In addition, the poor compliance of HIV positive patients, especially when drug addicts, is well known. On the other hand, the relatively short period of the study is justified by the lower expectation of life in HIV positive subjects with respect to the HIV negative ones.

Our results point out that the response to IFN in HIV positive patients with chronic hepatitis $\mathrm{C}$ is different from that observed in the HIV negative group.The histological outcome indicates an overall worsening of liver damage in HIV positive patients compared with HIV negative ones.

Pretreatment histological parameters have been indicated in several papers as possibly conditioning the response to treatment in HIV negative patients. High pretreatment scores of periportal and lobular necrosis are considered to be associated with high rates of response to the therapy, ${ }^{8} 20$ because they reflect activity of the immune system against $\mathrm{HCV}$, which could facilitate the immunomodulatory mechanism of IFN. On the contrary, the role of fibrosis is controversial: marked fibrosis may represent a disease of long duration that could lead to development of HCV strains resistant to IFN action, ${ }^{22}{ }^{23}$ causing a poor response to the therapy. However, other groups have not found a significantly decreased response to IFN in patients with a high fibrosis score or even cirrhosis. $^{924}$

In our study, the mean value of the scores for piecemeal and focal hepatocellular necrosis before the treatment were markedly higher in group A than in group B and, therefore, potentially more favourable; nevertheless, the response to the therapy was significantly worse for these subindices in group A than in group B. The scores of portal inflammation worsened in HIV positive patients and improved in the HIV negative patients but their changes were not statistically significant.

Finally, liver iron deposition, sometimes found in chronic hepatitis $\mathrm{C}$, has been reported to complicate the clinical course of hepatitis and modify the response to IFN..$^{25}{ }^{26}$ For these reasons, liver iron deposition was assessed on liver biopsies, and only traces of iron were found in lobuli and portal spaces; this was considered normal.

The different rates of response to IFN in HIV positive subjects with chronic hepatitis $C$ might be caused by several factors. The impairment of the immune system caused by HIV infection could induce greater replication of $\mathrm{HCV}$ and therefore more liver cell damage, as suggested by Martin et al. ${ }^{4}$ In our study, none of the HIV positive patients progressed to AIDS and CD4 counts remained over 200 cells $/ \mathrm{mm}^{3}$, suggesting that other factors could be responsible for the lower response to IFN. These could include a significantly lower immunomodulatory activity of IFN in HIV positive patients or a promoter effect of HIV on $\mathrm{HCV}$, as already demonstrated for other 
viruses. $^{27} 28$ Another cause of liver damage could be an indirect mechanism of the action of HIV. Scoazek et $a l^{29}$ demonstrated the presence of HIV receptors on Kupffer cells and hepatic sinusoidal cells; Housset et $a l^{30}$ provided immunohistochemical evidence of viral proteins in Kupffer cells and suggested that these cells may constitute a reservoir for HIV in the liver. In in vitro studies, Lafon $e t a l^{31}$ observed the presence of HIV particles in sinusoidal endothelium and Kupffer cells, in addition to various degrees of ultrastructural and functional damage. Damage to the endothelial barrier could modify the absorption of metabolites and drugs and, therefore, impair IFN efficacy.

In our study, IFN therapy produced an overall stabilisation of fibrosis in both groups of patients and no cases evolved to cirrhosis. In this respect, our results are similar to those of Marriott et al. ${ }^{12}$ In five out of the six patients who underwent liver biopsy they did not find cirrhosis after the treatment; in the sixth case cirrhosis was present before the treatment but it improved after treatment. Martin et $a l^{4}$ described three cases of chronic hepatitis $C$ in HIV positive patients that progressed rapidly to liver cirrhosis, but the patients were elderly, infected by blood transfusion, and were not treated with IFN.

Serological responses to the treatment were different between the two groups of patients, although the difference was statistically significant only for the virological response (clearance of serum HCV RNA), and not for the biochemical response.

The percentage of sustained responders of the non-HIV group was higher than those reported in the literature. ${ }^{18}$ This could be a reflection of the different groups studied: the young age, infection by drug addiction, and the especially high incidence of the HCV genotype $3 a$ in our patients have been reported as prognostically favourable conditions. ${ }^{32}$

Our data for HIV positive patients are different from those of Boyer $e t a l^{10}$ and Marriott $e t$ $a .^{12}$ The former reported complete or nearly complete responses to IFN in $58 \%$ of HIV positive patients with chronic hepatitis C; however, these patients were treated for only four to six months and did not undergo a comparable follow up. In the work by Marriott et al, ${ }^{12}$ only nine out of 14 patients completed the therapy and four of them were sustained responders (45\%) and were negative for HCV RNA six months after the end of the therapy. These differences in results could be explained by the better immunological status of their patients (mean CD4 cell count more than 580 cells/ $\mathrm{mm}^{3}$ ) than ours (mean CD4 cell count 465 cells $/ \mathrm{mm}^{3}$ ), and by the different schedules of treatment.

The rate of response to IFN has been reported to be connected with HCV genotypes; genotype $3 \mathrm{a}$ in particular is strongly associated with a high rate of response to IFN. ${ }^{6}{ }^{32}$ In our study, the outcome of chronic hepatitis $\mathrm{C}$ in HIV positive cases seems not to have been related to the viral genotypes. In fact, one out of six patients from group A with genotype $3 \mathrm{a}$ had a sustained response; while five out of six cases of HIV negative patients with genotype 3a were sustained responders.

Although no definitive conclusions can be drawn, owing to the small number of cases and the relatively short period studied, the treatment of chronic hepatitis C with IFN therapy produces lesser rates of response in HIV infected patients than in HIV negative patients, as judged by serological and histological parameters. Nevertheless, because IFN therapy seems to prevent the progression of fibrosis, HIV positive patients should still be treated in view of their more rapid progression to liver cirrhosis as reported in the literature. ${ }^{4}$

1 Hayashi PH, Flynn N, Stephen A. Prevalence of hepatitis C virus antibody among patients infected with human immunodeficiency virus. F Med Virol 1991;33:177-80.

2 Quann CM, Krajden M, Grigoriew GA, Salit IE. Hepatitis Quann CM, Krajden M, Grigoriew GA, Salit IE. Hepatitis $C$ virus infection in patients infected with human
deficiency virus. Clin Infect Dis 1993;17:1 17-19.

3 Berk L, Schalm SW, Heijtink RA. Severe chronic active hepatitis (autoimmune type) mimicked by coinfection of hepatitis $\mathrm{C}$ and human immunodeficiency viruses. Gut 1991;32:1 198-200.

4 Martin P, Di Bisceglie AM, Kassianides C, Lisker-Melman $\mathrm{M}$, Hoofnagle $\mathrm{JH}$. Rapidly progressive non-A, non-B hepatitis in patients with human immunodeficiency virus infection. Gastroenterology 1989;97:1559-61.

5 D’Arminio Monforte A, Vago L, Lazzarin A, Boldorini R, Bini T, Guzzetti S, et al. AIDS-defining diseases in 250 Bini T, Guzzetti S, et al. AIDS-defining diseases in 250
HIV-infected patients; a comparative study of clinical and HIV-infected patients; a comparative study
autopsy diagnoses. AIDS 1992;6:1 159-64.

6 Di Bisceglie AM, Martin P, Kassianides C, Lisker-Melman M, Murray L, Waggoner J, et al. Recombinant alpha interferon therapy for chronic hepatitis C. $N$ Engl f Med 1989 321:1506-10

7 David E, Pucci A, Palladin D, Saracco G, Garello E, Pintus $\mathrm{C}$, et al. Histologic changes in liver biopsy specimens produced by recombinant interferon $\alpha 2 \mathrm{~b}$ therapy for chronic non-A non-B chronic viral hepatitis. Am $\mathscr{f}$ Clin Pathol 1992;98:397-401.

8 De Alava E, Camps J, Pardo-Mindàn J, Garcia-Granero $M$ Munoz M, Sola J, et al. Histologic outcome of chronic hepatitis C treated with a 12 -month course of lymphoblastoid alpha interferon. Liver 1993;13:73-9.

9 Schvarcz R, Glaumann H, Weiland O, Norkrans G. Histologic outcome in interferon alpha-2b treated patients with chronic posttransfusion non-A, non-B hepatitis. Liver 1991;11:30-8.

10 Boyer N, Marcellin P, Degott C, Degos F, Gérard Saimot A, Erlinger S, Benhamou JP, and the Comite des Anti-Viraux. Recombinant interferon $\alpha$ for chronic hepatitis $C$ in patients positive for antibody to human immunodeficiency patients positive for antibody to
virus. $\mathcal{F}$ Infect Dis 1992;16:723-6.

11 Dalton BH, Acosta A, Jacobson IM. Interferon therapy in HIV positive patients with chronic hepatitis $C$ [abstract]. Hepatology 1992;16:199A.

12 Marriott E, Navas S, del Romero J, Garcia S, Castillo I, Quiroga JA, et al. Treatment with recombinant $\alpha$-interferon of chronic C hepatitis in anti-HIV positive patients. $\mathcal{f} \mathrm{Med}$ Virol 1993;40:107-11.

13 Stuyver L, Rossau R, Wyseur A, Duhamel M, Vanderborght $B$, Van Heuverswyn $\mathrm{H}$, et al. Typing of hepatitis $\mathrm{C}$ virus isolates and characterization of new subtypes using a line probe assay. $\mathcal{F}$ Gen Virol 1993;74:1093-102.

14 Knodell RG, Ishak KG, Black WC, Chen TS, Craig R, Kaplowits $\mathrm{N}$, et al. Formulation and application of a numerical scoring system for assessing histological activity in asymptomatic chronic active hepatitis. Hepatology 1981; in asymp.

15 Desmet V J, Gerber M, Hoofnagle JH, Manns M, Scheuer PS. Classification of chronic hepatitis: diagnosis, grading and staging. Hepatology 1994;19:1513-20.

16 Searle JW, Kerr JFR, Halliday JW, Powell LW. Iron storage disease. In MacSween RNM, Antony PP, Scheuer PJ, eds. Pathology of the liver. 2nd edn. Edinburgh: Churchill Livingston, 1987.

17 Simmonds P, Alberti A, Alter HJ, Bonino F, Bradley DW, Brechot C, et al. A proposed system for the nomenclature of hepatitis C viral genotypes. Hepatology 1994;19:1321-4.

8 Saracco G, Rosina F, Abate ML, Chiandussi L, Gallo V, Cerutti E, et al. Long term follow-up of patients with chronic hepatitis $\mathrm{C}$ treated with different doses of interferon. Hepatology 1993;18:300-5.

19 Diodati G, Bonetti P, Noventa F, Casarin C, Rugge M Scaccabarozzi S, et al. Treatment of chronic hepatitis $C$ with recombinant human interferon: results of a randomized controlled clinical trial. Hepatology 1994;19:1-5.

20 Omata M, Ito Y, Yokosuka O. Histological changes of the liver by treatment of chronic non-A non-B hepatitis with recombinant leukocyte interferon alpha. Comparision with histological changes in chronic hepatitis B. Dig Dis $S_{c i}$ 1989;34:330-7.

21 Pagliaro L, Craxì A, Cammaà C, Tinè F, Di Marco V, Lo Iacono $\mathrm{O}$, et al. Interferon alpha for chronic hepatitis $\mathrm{C}$ : an 
analysis of pretreatment clinical predictors of response. Hepatology 1994;19:820-8.

22 Tsubota A, Chayama K, Ikeda K, Yasuji A, Koida I, Saitoh $\mathrm{S}$, et al. Factors predictive of response to interferon alph therapy in hepatitis C virus infection. Hepatology 1994;19: 1088-94.

23 Jouet P, Roudot Thoraval F, Dhumeaux D, Métreau JM, and le Groupe Francais pour l'Etude du Traitement des Hépatites Chroniques NANB/C. Comparative efficacy of interferon alpha in cirrhotic and non cirrhotic patients with non-A non-B, C hepatitis. Gastroenterology 1994;106:68690.

24 Saito $T$, Shinzawa $H$, Kuboki $M$. A randomized controlled trial of human lymphoblastoid interferon in patients with compensated type C cirrhosis. Am f Gastroenterol 1994;89: 681-6.

25 Olynyk JK, Rajender Reddy K, Di Bisceglie AM, Jeffers LJ, Parker TI, Radick JL, et al. Hepatic iron concentration as predictor of response to interferon alpha therapy in chronic hepatitis C. Gastroenterology 1995;108:1 104-9.

26 Barton AL, Banner BF, Cable EE, Bonkovsky HL Distribution of iron in the liver predicts the response of chronic hepatitis $\mathrm{C}$ infection to interferon therapy. $\mathrm{Am} f$ Clin Pathol 1995;103:419-24.

27 Heng M, Heng SY, Allen S. Coinfection and synergy of human immunodeficiency virus- 1 and herpes simplex virus-1. Lancet 1994;343:255-8.

28 Tada H, Rappaport J, Lashgari M. Transactivation of the JC virus late promoter by the TAT protein of type one human immunodeficiency virus in glial cells. Proc Natl Acad Sci USA 1990;87:3476-83.

29 Scoazec JI, Feldmann J. Both macrophages and endothelia cells of the human hepatic sinusoid express the CD4 molecule, a receptor for the human immunodeficiency virus. Hepatology 1990;12:505-10.

30 Housset C, Boucher O, Girard PM. Immunohistochemical evidence for human immunodeficiency virus-1 infection of liver Kupffer cells. Hum Pathol 1990;21:404-8.

31 Lafon ME Kirn A Human immunodeficiency virus infection of the liver. Semin Liver Dis 1992;12:197-204.

32 Martinot-Peignoux M, Marcellin P, Pouteau M, Castelnau C, Boyer N, Poliquin C, et al. Pretreatment serum hepatitis $\mathrm{C}$ virus RNA levels and hepatitis $\mathrm{C}$ virus genotype are the main and independent prognostic factors of sustaine response to interferon alpha therapy in chronic hepatitis C. Hepatology 1995;22:1050-6.

33 Hino K, Sainokami S, Shimoda K, Iiono S, Wang Y, Okamoto $\mathrm{H}$, et al. Genotype and titers of hepatitis $\mathrm{C}$ virus for predicting response to interferon in patients with chronic hepatitis C. 7 Med Virol 1994;42:299-305. 